\title{
Integrating Soil Solarization and Seed Biopriming to Manage Seedling Damping-Off in Flower Nurseries
}

\author{
Deepa Khulbe* \\ Regional Research \& Technology Transfer Station (Coastal Zone), Orissa University of \\ Agriculture \& Technology, Bhubaneswar, India \\ *Corresponding author
}

\section{Keywords}

Floriculture nursery,

Solarization,

Damping-off,

Polyethylene

thickness, Seed

biopriming

Article Info

Accepted:

12 January 2019

Available Online:

10 February 2019

A B S T R A C T

The effect of soil solarization for a month in integration with seed biopriming with Trichoderma harzianum and Pseudomonas fluorescens and seed treatment with fungicides was studied in two flower crop nurseries of calendula and aster, raised in succession. Nursery beds were solarized for 30 days using polyethylene sheet of three colours viz. transparent white, black and red; and three thicknesses (50G, 200G and 400G). The damping-off incidence in first crop (Calendula) was minimum (28.6 per cent) in plots solarized with 400 gauge white polyethylene 8in combination with Vitavax seed treatment as compared to the 89.5 per cent damping-off in non-solarized control plots. An increase of $10-12{ }^{\circ} \mathrm{C}$ in average weekly soil temperature was recorded in solarized soil with maximum soil temperature ranging between $50-54^{\circ} \mathrm{C}$ in soil mulched with white or red polyethylene sheet. The effect of solarization lasted even after 60 days of solarization as the damping-off incidence in second nursery crop too was minimum (30.0\%) in plots solarized with 400 gauge white polyethylene in combination with biopriming with $P$. fluorescence as compared to the 63.6 per cent damping off in non-solarized control plots. The performance of soil solarization with polyethylene sheets of different colours and thickness were at par in terms of reduction of damping off in aster. Significant increase in the seedling growth was observed due to the soil solarization in all the treatments. Highest shoot length $(16.50 \mathrm{~cm})$ was observed in treatment involving solarization with 400 gauge polyethylene sheet in combination with Vitavax seed treatment, in calendula, as compared to the $3.3 \mathrm{~cm}$ shoot length in non-solarized control plots. Growth promontory effect of solarization was also observed in second nursery crop aster. Highest shoot length $(2.8 \mathrm{~cm})$ was observed in treatment involving solarization with 50 gauge polyethylene sheet in combination with no seed treatment.

\section{Introduction}

Most horticultural corps are raised from seeds in nurseries and then transplanted. Susceptibility to a wide range of soil borne pathogens capable of surviving for long periods of time in soil or plant debris is threatening to cultivation of these crops. Damping-off is the most serious problem encountered in raising nursery seedlings caused by over a dozen genera of various soilborne fungi including Rhizoctonia, Fusarium, 
Sclerotium and fungal-like organisms belonging to oomycetes (species of Pythium and Phytophthora) and some other seed-borne fungi (1). Damping off of seedlings is reported to affect up to 5 to $80 \%$ of the seedlings and thereby induce heavy economic losses and once established in the nursery soil, damping-off pathogens are able to survive in the soil for many years, even in the absence of host plants, either as saprophytes or as resting structures that are capable of surviving the adverse conditions $(22,25)$.

Nursery health is of immense importance for profitable and sustainable cultivation of flower crops, through the production of healthy seedlings. It is well recognized that due to seed rots, seedling rot and dampingoff, considerable plant population is lost causing loss of seed, the high value input, in case of many horticultural and ornamental crops and also the indirect cost of replanting. To produce healthy seedlings, soil health plays an important role, however none of the disease management techniques available presently, could bring the level of soil sanitation above critical threshold, where it could reduce seed and seedling diseases (7, $21,32,37)$. The routine sanitation approaches and soil sterilization / disinfestation with fumigants or non-fumigant chemical disinfectants posing environmental hazards, are not compatible with sustainable agriculture $(6,17)$. Soil solarization is a very simple and low-cost sustainable technique harnessing solar energy for managing soil borne diseases that improves soil health especially in nurseries and requires no special scientific know-how (19). This technique is useful for managing a wide spectrum of soilborne pests including fungi, bacteria, nematodes, weeds and insects in growing horticultural and floricultural crop nurseries, which has become a remunerative venture now a days $(5,15,20,27,38)$.
Soil solarization is a process to capture the solar radiations/energy for hydrothermal heating of soil layers resulting in direct thermal inactivation of pathogen propagules, enhanced soil microbial antagonism and improved plant growth response. For management of soil borne pathogens and pests, soil solarization has been accepted worldwide as an eco-friendly alternative to chemical soil disinfestation/ fumigation which poses serious adverse effects on soil, water and air. Hence, it is the most suited technology for non-chemical soil disinfestation and as a component of IPM in horticultural nurseries $(10,20,34,21)$

With this context, the study was conducted to assess the efficacy of soil solarization for a month in integration with seed bio-priming with Trichoderma harzianum and Pseudomonas fluorescens and seed treatment with fungicides in calendula and aster nursery beds on the incidence of damping-off of seedlings and seedling growth following single event of soil solarization using polyethylene sheet of three different (white transparent, black and red) colours and thickness (50 gauge, 200 gauge and 400 gauge).

\section{Materials and Methods}

The study was carried out at G. B. Pant University of Agriculture and Technology, Pantnagar, India located at $29^{\circ} \mathrm{N}$ and $73.3^{\circ} \mathrm{E}$ and an altitude of $243.84 \mathrm{~m}$ above the mean sea level agroclimatically falling under humid sub-tropical zone located at foothills of South Shivalik Ranges of the Himalayas. The soil of the experimental site was clay loam soil with soil $\mathrm{pH} 6.8$ which was used for raising nurseries of different annual and biennial flowers for several years. The experiment was laid in split plot design with three replications with three polyethylene sheet colours viz. white transparent, black and red, taking three 
polyethylene thicknesses viz. 50 gauge, 200 gauge and 400 gauge as main plot factor and five treatments including four seed treatments and one control as sub-plot factors. Five treatments given in each sub-plot included seed biopriming with Trichoderma harzianum and Pseudomonas fluorescens @ 4g per kg seed and treatment with Thiram and Vitavax @ 2.5g per $\mathrm{kg}$ seed and non-treated control (Table 1). The bioagents Pant Bioagent-1 (Trichoderma harzianum) and Pant Bioagent2 (Pseudomonas fluorescens) were procured from Biocontrol Laboratory, Department of Plant Pathology, G. B. Pant University of Agriculture and Technology, Pantnagar.

For solarization of nursery soil, raised beds were prepared, irrigation was given to ensure optimum soil moisture (at field capacity) and beds were covered with polyethylene sheets of three different colours and thickness. The polyethylene sheets were buried into the soil from all sides of the nursery beds (Fig 1) to avoid moisture loss and any leakage of trapped heat for effective solarization during summer months for 30 days $\left(2^{\text {nd }}\right.$ July- $5^{\text {th }}$ Aug, 1999). Daily soil temperature during the entire period of solarization was recorded by placing soil-thermometers beneath the polyethylene film at depth of $5 \mathrm{~cm}$. The maximum daily temperatures were recorded at 2.30 P.M. and finally weekly average maximum temperature was computed.

After solarization, the polyethylene sheets were removed and the nursery of calendula was raised on solarized beds for 30 days and after that aster nursery was raised in the same beds in succession. To evaluate the effect of solarization on the incidence of damping-off, number of seeds expected or likely to germinate i.e., germination per cent (X), number of seeds actually germinated after 7 days of sowing (A) were counted using a telecounter. Damping-off incidences were computed by the following mathematical formula given bellow.
The plant growth response was assessed in terms of seedling shoot length and fresh seedling shoot weight. Seedling shoot length was recorded for seedlings uprooted at 30 days after sowing for 10 seedlings and average calculated. Fresh shoot weight was also recorded for the same 10 seedlings. The data so obtained, were subjected to statistical analysis and the mean values of three replications were presented in data tables.

\section{Results and Discussion}

\section{Effects of soil solarization on soil temperature}

Hydrothermal heating of soil layers is the major principle of soil solarization. When wet soil is mulched with polyethylene film, the heat/ solar radiations that penetrate the film are not allowed to be dissipated and lost. Covering of the soil with polyethylene, particularly the droplets that appear over the under-surface of the plastic sheet, ensures conservation of trapped heat. Thus, as per changes in the daily cycles of sunshine and darkness, the temperature status of the solarized soil also changes. It was observed that the temperature of the solarized soil, on an average, increased every week by about 10$12^{\circ} \mathrm{C}$ as the soil temperature ranged between $50-54^{\circ} \mathrm{C}$ in soil mulched with white or red polyethylene sheet. The increase in soil temperature of the soil mulched with black sheet did not increase to the extent observed with white and red sheet. The increase was about $2-4^{\circ} \mathrm{C}$ over the temperature under unmulched soil. The thickness of the polyethylene mulches did not cause any significant change in the soil temperature (Fig $2 \mathrm{a}$ ). The average soil temperature (at $5 \mathrm{~cm}$ depth) under all three colours was almost similar with all the thickness (Fig 2b).

Per cent incidence of seedling damping-off $=\frac{(\mathrm{X}-\mathrm{A}) \times 100}{\mathrm{~A}}$ 
Maximum soil temperature of $54^{\circ} \mathrm{C}$ was recorded with white transparent polyethylene sheet of $200 \mathrm{G}$ thickness as compared to $39.5^{\circ} \mathrm{C}$ in non-solarized soil. It was $52^{\circ} \mathrm{C}$ with red polyethylene sheet of $200 \mathrm{G}$ thickness however, in case of black polyethylene sheet, the maximum soil temperature of $42.2^{\circ} \mathrm{C}$ was recorded with 50G thickness. Maximum increase in soil temperature observed under white transparent, red and black polyethylene sheet was $12.9^{\circ} \mathrm{C}, \quad 10.7^{\circ} \mathrm{C}$ and $1.7^{\circ} \mathrm{C}$ respectively. Soil solarization additionally suppressed the weed population too, as compared to non-solarized plots as reported by Campiglia et al., (4). Except Cyperus rotundus almost all weed species were killed by soil solarization (Fig. 3b).

The success of solarization is based on the fact that most plant pathogens and pests are mesophilic $\left(20^{\circ} \mathrm{C}-45^{\circ} \mathrm{C}\right)$, i.e. they are typically unable to grow at temperatures above $32^{\circ} \mathrm{C}$. These soil borne pests are killed directly or indirectly by the temperatures achieved during solarization of the moist soil under transparent plastic films which greatly restrict the escape of volatiles gases and water vapours $(12,20)$. However, thermo-tolerant and thermophilic soil microflora (both inhabitants and invaders) usually survive the soil solarization process $(20,29,34)$. Soil solarization is reported to elevate the soil temperature by $6-10^{\circ} \mathrm{C}$ in $0-20 \mathrm{~cm}$ soil profile $(3,8,13)$. Direct hydrothermal inactivation of pathogen propagules as a consequence of raised soil temperature has been reported to have most pronounced lethal effects on a broad spectrum of soil organisms (14, 23, 24, 34). Accumulation of heat effect above a critical temperature threshold (about $37^{\circ} \mathrm{C}$ ) over time becomes lethal for mesophylic organisms. However, other soilborne organisms, if not directly inactivated by heat, may be weakened and become vulnerable to gases produced in solarized soil or to change in microflora and thus are managed/suppressed by one or other form of biocontrol (16, 19, 30, 36). The thermal decline of soilborne organisms during solar heating depends on both, the soil temperatures and exposure time which are inversely related.

Invariably higher temperature was recorded under white transparent mulch followed by red and black mulches with high temperature range and high soil heat flux distribution under transparent and red mulches as compared to black mulch which was strongly skewed toward lower values (2). It was concluded that heat flux is one of the components of the energy balance and is closely related to the amount of radiation transmitted through mulches. Widespread application of low density polyethylene (LDPE) for agricultural mulching has been advocated because of its flexibility, tensile strength and resistance to physical damage and polyethylene has been emphasized as an ideal film for solar heating of soil as it is essentially transparent to solar radiation (280 to $2500 \mathrm{~nm}$ ), extending to the far infra red, but much less transparent to terrestrial long wave radiation $(5000-35000 \mathrm{~nm})$, and thus reducing the escape of heat from the soil (7). The heating efficacy of different types of polyethylene is associated with its relative transmittance.

\section{Effect of solarization and seed biopriming on seedling damping-off incidence}

Soil solarization for a month using three colours (White transparent, red and black) and thickness of polyethylene (50, 200 and 400 gauge) in integration with seed biopriming with Trichoderma harzianum and Pseudomonas fluorescence, in flower crop nurseries of calendula and aster raised in succession in same plot, significantly reduced the incidence of damping-off of seedlings (Table 2 and 3). In calendula, significant 
reduction in the incidence of damping-off was recorded with seed treatments and solarization separately and also in integration. In nonsolarized plots, despite seed-treatment with fungicides or bioagent, the incidence of damping-off ranged from 64.8 to 81 per cent in calendula and from 51.5 to 56.9 per cent in aster. In plots solarized with white polyethylene, the incidence of damping-off reduced to the level of 29.8- 35.8 per cent however with black polyethylene sheet it ranged between 55.5 to 69.2 per cent and from 38.7 to 48 per cent with red polyethylene sheet in calendula. In case of aster, in plots solarized with white polyethylene, the incidence of damping-off reduced to the level of 35.0- 50.7 per cent, with black polyethylene sheet from 40.5 to 59.5 per cent and with red polyethylene sheet from 38.7 to 48 per cent.

Solarization with white transparent polyethylene of all the three thicknesses (50 gauge, 200 gauge and 400 gauge), significantly reduced the incidence of damping-off of seedlings in calendula. Percent increase in seedling emergence over control due to solarization ranged from 13.9 to 55.2 in calendula and from 0.5 to 18.9 in aster (Fig. 4) in solarized plots, even without seed-treatments. Gasoni et al., (18) also reported positive effect of soil solarization and biocontrol agents on plant stand and yield. Seed-treatment with bioagent or fungicides further enhanced the effects of solarization. It clearly indicated the efficacy of soil solarization in integration with chemical seed treatment and biopriming.

Solarization was most effective with white transparent polyethylene (thickness 50, 200 and 400 gauge) as the incidence of dampingoff was reduced significantly to the level of 28.8 per cent compared to 39.7 per cent with black PE-sheet and 37.7 per cent with red polyethylene sheet (Table 2). The damping- off incidence in calendula nursery crop was minimum (28.8 per cent) in plots solarized with 50 gauge white polyethylene in combination with Vitavax seed treatment as compared to the 89.5 per cent damping off in non-solarized control plots. Soil solarization with white polyethylene was significantly better than with black and red polyethylene in terms of reduction of damping off in calendula.

In case of aster nursery, incidence of damping-off was minimum $(30.0 \%)$ in plots solarized with 400 gauge white polyethylene + bio-priming with $P$. fluorescence as compared to the 63.6 per cent damping off in non-solarized control plots. However, it was recorded minimum $(38.3 \%)$ with $200 \mathrm{G}$ black PE sheet and (40\%) with $200 \mathrm{G}$ red PE sheet. The overall performance of soil solarization with transparent white polyethylene was significantly superior in reducing the damping off incidence however, as compared to black or red PE sheet.

The data recorded for seedling damping-off revealed significantly lower incidence of damping off under white transparent polyethylene sheet. Similarly significant decrease was reported in the incidence of damping-off in case of tomato, cauliflower and onion raised in nurseries and integration of solarization with seed treatment with fungicides like Thiram etc. and biocontrol agents further improved control of dampingoff of seedling as reported by Minuto et al., (26) and Mishra (28).

Solarization with white transparent PE sheet increased the seedling emergence in calendula up to $612 \%$ over control and up to $130.6 \%$ over control in aster raised in same solarized beds in succession (Fig 4). The per cent increase in seedling emergence over control was assessed $272.6 \%$ and $371.3 \%$ with black and red PE sheet respectively, in calendula and $120.3 \%$ and $137 \%$ in aster nursery. 
Effect of solarization and seed biopriming on seedling growth

Significant increase in the seedling growth was observed due to the soil solarization in all the treatments. In calendula, highest shoot length $(16.5 \mathrm{~cm})$ was observed in treatment involving solarization with 400 gauge polyethylene sheet + Vitavax seed treatment, as compared to the $3.3 \mathrm{~cm}$ shoot length under non-solarized control plots (Table 4). In aster nursery, significant effect of solarization was observed with white transparent polyethylene and highest shoot length $(2.87 \mathrm{~cm})$ was observed in treatment involving solarization with 50 gauge PE sheet even without any seed treatment. However, in plots solarized with black and red PE sheets, improvement in seedling length was statistically nonsignificant (Table 5).

Table.1 Details of the seed treatments / biopriming agents and their rates of application

\begin{tabular}{|l|l|l|}
\hline Fungicide / Bioagent & \multicolumn{1}{|c|}{ Chemical / Agent Name } & \multicolumn{1}{|c|}{ Rate of Application } \\
\hline Dithiocarbamate & Thiram & $2.5 \mathrm{~g} / \mathrm{kg}$ seed $(0.25 \%)$ \\
\hline Carboxin & Vitavax & $2.0 \mathrm{~g} / \mathrm{kg}$ seed $(0.20 \%)$ \\
\hline T. harzianum & Pant Bioagent-1(PB-1) of $1.5 \times 10^{9}$ c.f.u & $4.0 \mathrm{~g} / \mathrm{kg}$ seed $(0.4 \%)$ \\
\hline P. fluorescens & $\begin{array}{l}\text { Pant Bioagent-2 (PB-2) of } 1.5 \times \\
\text { 109c.f.u }\end{array}$ & $4.0 \mathrm{~g} / \mathrm{kg}$ seed $(0.4 \%)$ \\
\hline
\end{tabular}

Table.2 Effect of soil solarization in integration with seed-biopriming on incidence of seedling damping-off in calendula

\begin{tabular}{|c|c|c|c|c|c|c|c|c|c|c|c|c|c|}
\hline \multirow{3}{*}{ Treatments } & \multirow{3}{*}{$\begin{array}{l}\text { Non- } \\
\text { solarize } \\
\quad \text { d }\end{array}$} & \multicolumn{12}{|c|}{ Solarized } \\
\hline & & \multicolumn{4}{|c|}{ White Polyethylene } & \multicolumn{4}{|c|}{ Black Polyethylene } & \multicolumn{4}{|c|}{ Red Polyethylene } \\
\hline & & $50 \mathrm{G}$ & 200 & $400 \mathrm{G}$ & Mean & $50 \mathrm{G}$ & $200 \mathrm{G}$ & $400 \mathrm{G}$ & Mear & $50 \mathrm{G}$ & $200 \mathrm{G}$ & $400 \mathrm{G}$ & Mean \\
\hline Control & 89.5 & $\begin{array}{c}34 . \\
3\end{array}$ & $\begin{array}{c}36 . \\
0\end{array}$ & 37.9 & 36.1 & 75.6 & 67.5 & 71.0 & $\begin{array}{c}71 . \\
3\end{array}$ & 55.1 & 62.3 & $\begin{array}{c}65 . \\
7\end{array}$ & 61.0 \\
\hline Thiram & 81.0 & $\begin{array}{c}31 . \\
0\end{array}$ & $\begin{array}{c}33 . \\
0\end{array}$ & 38.3 & 34.1 & 39.7 & 63.8 & 74.2 & $\begin{array}{c}69 . \\
2\end{array}$ & 49.7 & 44.7 & $\begin{array}{c}48 . \\
9\end{array}$ & 47.7 \\
\hline Vitavax & 76.3 & $\begin{array}{c}28 . \\
8\end{array}$ & $\begin{array}{c}31 . \\
6\end{array}$ & 28.9 & 29.8 & 61.7 & 51.0 & 53.9 & $\begin{array}{c}55 . \\
5\end{array}$ & 40.6 & 38.0 & $\begin{array}{c}37 . \\
7\end{array}$ & 38.7 \\
\hline T. harzianum & 76.1 & $\begin{array}{c}29 . \\
5\end{array}$ & $\begin{array}{c}29 . \\
5\end{array}$ & 30.4 & 35.8 & 64.3 & 57.3 & 64.4 & $\begin{array}{c}62 . \\
0\end{array}$ & 51.0 & 50.5 & $\begin{array}{c}42 . \\
5\end{array}$ & 48.0 \\
\hline P. ftuorescens & 64.8 & $\begin{array}{c}38 . \\
6\end{array}$ & $\begin{array}{c}38 . \\
3\end{array}$ & 30.4 & 35.8 & 64.3 & 57.3 & 64.4 & $\begin{array}{c}62 . \\
0\end{array}$ & 51.0 & 50.5 & $\begin{array}{c}42 . \\
5\end{array}$ & 48.0 \\
\hline $\begin{array}{l}\text { Main plot } \\
\text { mean }\end{array}$ & 77.5 & $\begin{array}{c}32 . \\
5\end{array}$ & $\begin{array}{c}33 . \\
7\end{array}$ & 33.2 & 33.1 & 67.0 & 59.3 & 63.6 & $\begin{array}{c}63 . \\
3\end{array}$ & 48.1 & 49.9 & $\begin{array}{c}48 . \\
9\end{array}$ & 49.0 \\
\hline \multicolumn{2}{|l|}{ CD at $5 \%$} & \multicolumn{4}{|c|}{$\begin{array}{l}\mathrm{CD}_{1}=4.06 \\
\mathrm{CD}_{2}=5.64 \\
\mathrm{CD}_{3}=11.3 \\
\mathrm{CD}_{4}=10.8\end{array}$} & \multicolumn{4}{|c|}{$\begin{array}{l}\mathrm{CD}_{1}-4.30 \\
\mathrm{CD}_{2}-7.95 \\
\mathrm{CD}_{3}=15.91 \\
\mathrm{CD}_{4}=14.80\end{array}$} & \multicolumn{4}{|c|}{$\begin{array}{l}\mathrm{CD}_{1}=7.60 \\
\mathrm{CD}_{2}=6.31 \\
\mathrm{CD}_{3}=12.6 \\
\mathrm{CD}_{4}=13.5\end{array}$} \\
\hline
\end{tabular}


Table.3 Effect of soil solarization in integration with seed bio-biopriming on incidence of seedling damping-off in aster

\begin{tabular}{|c|c|c|c|c|c|c|c|c|c|c|c|c|c|}
\hline \multirow[t]{3}{*}{ Treatments } & \multirow{3}{*}{$\begin{array}{l}\text { Non- } \\
\text { solarize } \\
\text { d }\end{array}$} & \multicolumn{12}{|c|}{ Solarized } \\
\hline & & \multicolumn{4}{|c|}{ White polyethylene } & \multicolumn{4}{|c|}{ Black polyethylene } & \multicolumn{4}{|c|}{ Red polyethylene } \\
\hline & & $50 \mathrm{G}$ & $200 G$ & $400 \mathrm{G}$ & Mean & $50 \mathrm{G}$ & $200 \mathrm{G}$ & $400 \mathrm{G}$ & Mean & $50 \mathrm{G}$ & $200 \mathrm{G}$ & $400 \mathrm{G}$ & Mean \\
\hline Control & 63.6 & 52.1 & 50.3 & 55.1 & 52.5 & 56.4 & 58.5 & 63.1 & 59.3 & 52.1 & 53.7 & 54.7 & 53.5 \\
\hline Thiram & 56.9 & 52.9 & 49.6 & 49.7 & 50.7 & 55.3 & 62.8 & 60.6 & 59.5 & 53.0 & 49.8 & 46.7 & 49.8 \\
\hline Vitaavax & 56.3 & 49.3 & 41.2 & 40.0 & 43.5 & 47.2 & 51.2 & 46.3 & 46.2 & 50.0 & 42.1 & 47.6 & 46.6 \\
\hline T. harzianum & 56.9 & 46.3 & 35.8 & 40.0 & 40.7 & 39.3 & 38.3 & 44.1 & 40.5 & 43.8 & 44.9 & $42-8$ & 43.8 \\
\hline P. fluorescens & 51.5 & 36.9 & 38.2 & 30.0 & 35.0 & 42.1 & 44.9 & 43.7 & 43.5 & 48.2 & 40.0 & 40.2 & 42.8 \\
\hline Main plot mear & 57.0 & 47.5 & 43.0 & 42.9 & 44.5 & 48.1 & 51.1 & 51.6 & 50.2 & 49.4 & 46.1 & 46.4 & 47.3 \\
\hline \multicolumn{2}{|c|}{ CD at $5 \%$} & \multicolumn{4}{|c|}{$\begin{array}{l}\mathrm{CD}_{1}=10.1 \\
\mathrm{CD}_{2}=11.4 \\
\mathrm{CD}_{3}=22.8 \\
\mathrm{CD}_{4}=22.7\end{array}$} & \multicolumn{4}{|c|}{$\begin{array}{c}\mathrm{CD}_{1}=14.94 \\
\mathrm{CD}_{2}=8.62 \\
\mathrm{CD}_{3}=17.23 \\
\mathrm{CD}_{4}=21.38\end{array}$} & \multicolumn{4}{|c|}{$\begin{array}{l}\mathrm{CD}_{1}=7.40 \\
\mathrm{CD}_{2}=9.90 \\
\mathrm{CD}_{3}=19.8 \\
\mathrm{CD}_{4}=19.1\end{array}$} \\
\hline \multicolumn{14}{|c|}{$\begin{array}{l}\text { * Details of } \mathrm{CD} \text { values } \\
\mathrm{CD}_{1}=\text { for comparing main plot means }\end{array}$} \\
\hline
\end{tabular}

Table.4 Effect of soil solarization and its integration with seed-biopriming on seedling shoot length $(\mathrm{cm})$ of calendula (each value is average of 10 readings)

\begin{tabular}{|c|c|c|c|c|c|c|c|c|c|c|c|c|c|}
\hline \multirow[t]{3}{*}{ Treatments } & \multirow{3}{*}{$\begin{array}{c}\text { Non- } \\
\text { Solarize } \\
\text { d }\end{array}$} & \multicolumn{12}{|c|}{ Solarized } \\
\hline & & \multicolumn{4}{|c|}{ White polyethylene } & \multicolumn{4}{|c|}{ Black polyethylene } & \multicolumn{4}{|c|}{ Red polyethylene } \\
\hline & & $50 \mathrm{G}$ & $200 \mathrm{G}$ & $400 \mathrm{G}$ & Mean & $50 \mathrm{G}$ & $200 \mathrm{G}$ & $400 \mathrm{G}$ & Mean & $50 \mathrm{G}$ & $200 \mathrm{G}$ & $400 \mathrm{G}$ & Mean \\
\hline Control & 3.30 & 10.50 & 11.51 & 12.07 & 11.36 & 4.96 & 6.01 & 5.47 & 5.48 & 8.00 & 7.00 & 7.53 & 7.51 \\
\hline Thiram & 3.42 & 12.80 & 12.90 & 14.60 & 13.43 & 8.05 & 7.73 & 7.18 & 7.65 & 8.70 & 8.90 & 9.46 & 9.02 \\
\hline Vitavax & 4.62 & 14.70 & 14.60 & 16.50 & 15.26 & 6.94 & 8.96 & 3.12 & 8.00 & 9.96 & 10.20 & 10.91 & 10.35 \\
\hline T. harzianum & 4.47 & 13.30 & 14.80 & 13.40 & 13.80 & 9.14 & 7.91 & 9.20 & 8.75 & 9.20 & 10.70 & 10.43 & 10.11 \\
\hline P. fluorescens & 4.45 & 12.05 & 14.50 & 13.50 & 13.50 & 10.0 & 9.20 & 3.50 & 9.23 & 9.20 & 9.80 & 10.40 & 9.80 \\
\hline $\begin{array}{c}\text { Main plot } \\
\text { mean }\end{array}$ & 4.05 & 12.60 & 13.80 & 14.20 & 13.47 & 7.83 & 7.96 & 7.70 & 7.83 & 9.00 & 9.30 & 9.75 & 9.35 \\
\hline \multirow{4}{*}{\multicolumn{2}{|c|}{ CD at $5 \%$}} & \multicolumn{4}{|c|}{$\mathrm{CD}_{1}=1.24$} & \multicolumn{4}{|c|}{$\mathrm{CD}_{1}=1.42$} & \multicolumn{4}{|c|}{$\mathrm{CD}_{1}-1.47$} \\
\hline & & \multicolumn{4}{|c|}{$\mathrm{CD}_{2}-1.09$} & \multicolumn{4}{|c|}{$\mathrm{CD}_{2}=0.97$} & \multicolumn{4}{|c|}{$\mathrm{CD}_{2}=0.85$} \\
\hline & & \multicolumn{4}{|c|}{$\mathrm{CD}_{3}=2.17$} & \multicolumn{4}{|c|}{$\mathrm{CD}_{3}=1.93$} & \multicolumn{4}{|c|}{$\mathrm{CD}_{3}=1.70$} \\
\hline & & \multicolumn{4}{|c|}{$\mathrm{CD}_{4}=2.30$} & \multicolumn{4}{|c|}{$\mathrm{CD}_{4}=2.23$} & \multicolumn{4}{|c|}{$\mathrm{CD}_{4}=2.11$} \\
\hline
\end{tabular}


Table.5 Effect of soil solarization and its integration with seed-biopriming on seedling shoot length $(\mathrm{cm})$ of aster

\begin{tabular}{|c|c|c|c|c|c|c|c|c|c|c|c|c|c|}
\hline \multirow[t]{3}{*}{ Treatments } & \multirow{3}{*}{$\begin{array}{c}\text { Non- } \\
\text { Solarized }\end{array}$} & \multicolumn{12}{|c|}{ Solarized } \\
\hline & & \multicolumn{4}{|c|}{ White polyethylene } & \multicolumn{4}{|c|}{ Black polyethylene } & \multicolumn{4}{|c|}{ Red polyethylene } \\
\hline & & $50 \mathrm{G}$ & $\begin{array}{c}200 \\
\mathrm{G}\end{array}$ & $400 \mathrm{G}$ & Mean & $50 \mathrm{G}$ & $200 \mathrm{G}$ & $400 \mathrm{G}$ & Mean & $50 \mathrm{G}$ & $200 \mathrm{G}$ & $400 \mathrm{G}$ & Mean \\
\hline Control & 1.16 & 2.87 & 2.71 & 2.47 & 2.68 & 1.54 & 1.33 & 1.36 & 1.41 & 1.64 & 1.86 & 1.97 & 1.80 \\
\hline Thiram & 1.80 & 2.16 & 2.20 & 2.40 & 2.25 & 1.64 & 1.66 & 1.71 & 1.67 & 1.96 & 2.00 & 2.37 & 2.11 \\
\hline Vitavax & 1.62 & 2.30 & 2.47 & 2.48 & 2.41 & 2.00 & 1.83 & 1.85 & 1.89 & 2.09 & 1.98 & 2.00 & 2.02 \\
\hline T. harzianum & 1.85 & 2.60 & 2.33 & 2.36 & 2.43 & 1.7 & 2.09 & 2.57 & 2.14 & 2.37 & 2.30 & 2.40 & 2.35 \\
\hline P. fluorescens & 1.81 & 2.20 & 2.65 & 2.30 & 2.38 & 2.10 & 2.16 & 2.41 & 2.22 & 2.13 & 2.36 & 2.52 & 2.33 \\
\hline Mean & 1.62 & 2.42 & 2.47 & 2.40 & 2.43 & 1.81 & 1.81 & 1.98 & 1.86 & 2.04 & 2.10 & 2.25 & 2.13 \\
\hline \multirow{4}{*}{\multicolumn{2}{|c|}{ CD at $5 \%$}} & \multicolumn{4}{|c|}{$\mathrm{CD}_{1}=0.56$} & \multicolumn{4}{|c|}{$\mathrm{CD}_{1}=0.31$} & \multicolumn{4}{|c|}{$\mathrm{CD}_{1}=0.49$} \\
\hline & & \multicolumn{4}{|c|}{$\mathrm{CD}_{2}=0.40$} & \multicolumn{4}{|c|}{$\mathrm{CD}_{2}=0.35$} & \multicolumn{4}{|c|}{$\mathrm{CD}_{2}=0.39$} \\
\hline & & \multicolumn{4}{|c|}{$\mathrm{CD}_{3}=0.81$} & \multicolumn{4}{|c|}{$\mathrm{CD}_{3}=0.70$} & \multicolumn{4}{|c|}{$\mathrm{CD}_{3}=0.76$} \\
\hline & & \multicolumn{4}{|c|}{$\mathrm{CD}_{4}=0.91$} & \multicolumn{4}{|c|}{$\mathrm{CD}_{4}=0.69$} & \multicolumn{4}{|c|}{$\mathrm{CD}_{4}=0.86$} \\
\hline
\end{tabular}

Table.6 Effect of soil solarization and its integration with seed-biopriming on fresh seedling (10 seedlings) shoot weight ( $\mathrm{g}$ ) of calendula

\begin{tabular}{|c|c|c|c|c|c|c|c|c|c|c|c|c|c|}
\hline \multirow[t]{3}{*}{ Treatments } & \multirow{3}{*}{$\begin{array}{c}\text { Non- } \\
\text { Solarized }\end{array}$} & \multicolumn{12}{|c|}{ Solarized } \\
\hline & & \multicolumn{4}{|c|}{ White polyethylene } & \multicolumn{4}{|c|}{ Black polyethylene } & \multicolumn{4}{|c|}{ Red polyethylene } \\
\hline & & $50 \mathrm{G}$ & $200 \mathrm{G}$ & $400 \mathrm{G}$ & Mean & $50 \mathrm{G}$ & $200 \mathrm{G}$ & $400 \mathrm{G}$ & Mean & $50 \mathrm{G}$ & $200 \mathrm{G}$ & $400 \mathrm{G}$ & Mean \\
\hline Control & 1.79 & 3.80 & 4.10 & 4.50 & 4.13 & 1.73 & 2.37 & 2.55 & 2.21 & 2.71 & 2.85 & 3.20 & 2.92 \\
\hline Thiram & 2.12 & 5.30 & 4.97 & 5.00 & 5.09 & 2.63 & 2.63 & 3.01 & 2.75 & 2.95 & 3.07 & 3.45 & 3.15 \\
\hline Vitavax & 1.91 & 4.90 & 4.80 & 5.32 & 5.00 & 2.71 & 2.96 & 2.76 & 2.81 & 3.16 & 3.33 & 3.51 & 3.33 \\
\hline T. harzianum & 1.70 & 4.70 & 5.00 & 4.40 & 4.70 & 3.53 & 3.41 & 3.40 & 3.44 & 3.54 & 3.75 & 3.62 & 3.63 \\
\hline P. fluorescens & 1.87 & 4.00 & 4.77 & 4.90 & 4.55 & 3.44 & 3.35 & 3.45 & 3.45 & 3.38 & 3.68 & 3.82 & 3.62 \\
\hline Main plot mean & 1.87 & 4.50 & 4.74 & 4.80 & 4.68 & 2.81 & 2.94 & 3.03 & 2.93 & 3.15 & 3.33 & 3.52 & 3.33 \\
\hline \multicolumn{2}{|c|}{$\mathrm{CD}$ at $5 \%$} & \multicolumn{4}{|c|}{$\begin{array}{l}\mathrm{CD}_{1}=0.63 \\
\mathrm{CD}_{2}=1.56 \\
\mathrm{CD}_{3}=0.47 \\
\mathrm{CD}_{4}=1.10\end{array}$} & \multicolumn{4}{|c|}{$\begin{array}{l}\mathrm{CD}_{1}=0.23 \\
\mathrm{CD}_{2}=0.43 \\
\mathrm{CD}_{3}=0.87 \\
\mathrm{CD}_{4}-0.81\end{array}$} & \multicolumn{4}{|c|}{$\begin{array}{l}\mathrm{CD}_{1}=0.47 \\
\mathrm{CD}_{2}=0.35 \\
\mathrm{CD}_{3}=0.71 \\
\mathrm{CD}_{4}=0.78\end{array}$} \\
\hline
\end{tabular}


Table.7 Effect of soil solarization and its integration with seed-biopriming on fresh seedling (10 seedlings) shoot weight ( $\mathrm{g}$ ) of aster

\begin{tabular}{|c|c|c|c|c|c|c|c|c|c|c|c|c|c|}
\hline \multirow[t]{3}{*}{ Treatments } & \multirow{3}{*}{$\begin{array}{c}\text { Non- } \\
\text { Solarized }\end{array}$} & \multicolumn{12}{|c|}{ Solarized } \\
\hline & & \multicolumn{4}{|c|}{ White polyethylene } & \multicolumn{4}{|c|}{ Black polyethylene } & \multicolumn{4}{|c|}{ Red polyethylene } \\
\hline & & $50 \mathrm{G}$ & $200 \mathrm{G}$ & $400 \mathrm{G}$ & Mean & $50 \mathrm{G}$ & $200 G$ & $400 \mathrm{G}$ & Mean & $50 \mathrm{G}$ & $200 \mathrm{G}$ & $400 \mathrm{G}$ & Mean \\
\hline Non treated & 5.8 & 10.2 & 10.0 & 11.6 & 10.6 & 8.5 & 9.9 & 9.7 & 9.4 & 11.1 & 10.1 & 13.3 & 11.5 \\
\hline Thiram & 7.2 & 12.4 & 10.5 & 12.5 & 11.8 & 8.6 & 13.1 & 13.2 & 11.6 & 12.1 & 13.5 & 14.2 & 11.7 \\
\hline Vitavax & 8.1 & 13.0 & 12.0 & 13.2 & 12.7 & 9.2 & 12.2 & 12.7 & 11.3 & 14.3 & 11.4 & 13.2 & 12.5 \\
\hline T. harzianum & 9.4 & 13.4 & 13.1 & 13.3 & 13.2 & 10.7 & 15.0 & 10.6 & 11.9 & 13.4 & 14.4 & 15.0 & 13.1 \\
\hline P. fluorescens & 8.8 & 14.2 & 14.8 & 13.7 & 14.2 & 10.3 & 13.4 & 13.5 & 12.4 & 13.1 & 14.4 & 15.6 & 13.0 \\
\hline Mean & 7.8 & 12.6 & 12.1 & 12.8 & 12.5 & 9.34 & 12.7 & 11.9 & 11.3 & 12.9 & 12.8 & 16.2 & 12.3 \\
\hline \multicolumn{2}{|c|}{$\mathrm{CD}$ at $5 \%$} & & $\mathrm{CD}_{3}=2$ & $\begin{array}{r}\mathrm{CD} \\
\mathrm{CD} \\
63 \mathrm{CD}\end{array}$ & $\begin{array}{l}=1.56 \\
=1.31 \\
=2.81\end{array}$ & & $\mathrm{CD}_{3}=4$ & $\begin{array}{r}\mathrm{CD} \\
\mathrm{CD} \\
57 \mathrm{CD}\end{array}$ & $\begin{array}{l}=2.20 \\
=2.28 \\
=4.63\end{array}$ & \multicolumn{4}{|c|}{$\begin{array}{r}\mathrm{CD}_{2}=2.10 \\
\mathrm{CD}-4\end{array}$} \\
\hline
\end{tabular}

Fig.1 Steps involved in polyethylene sheet covering of the nursery beds

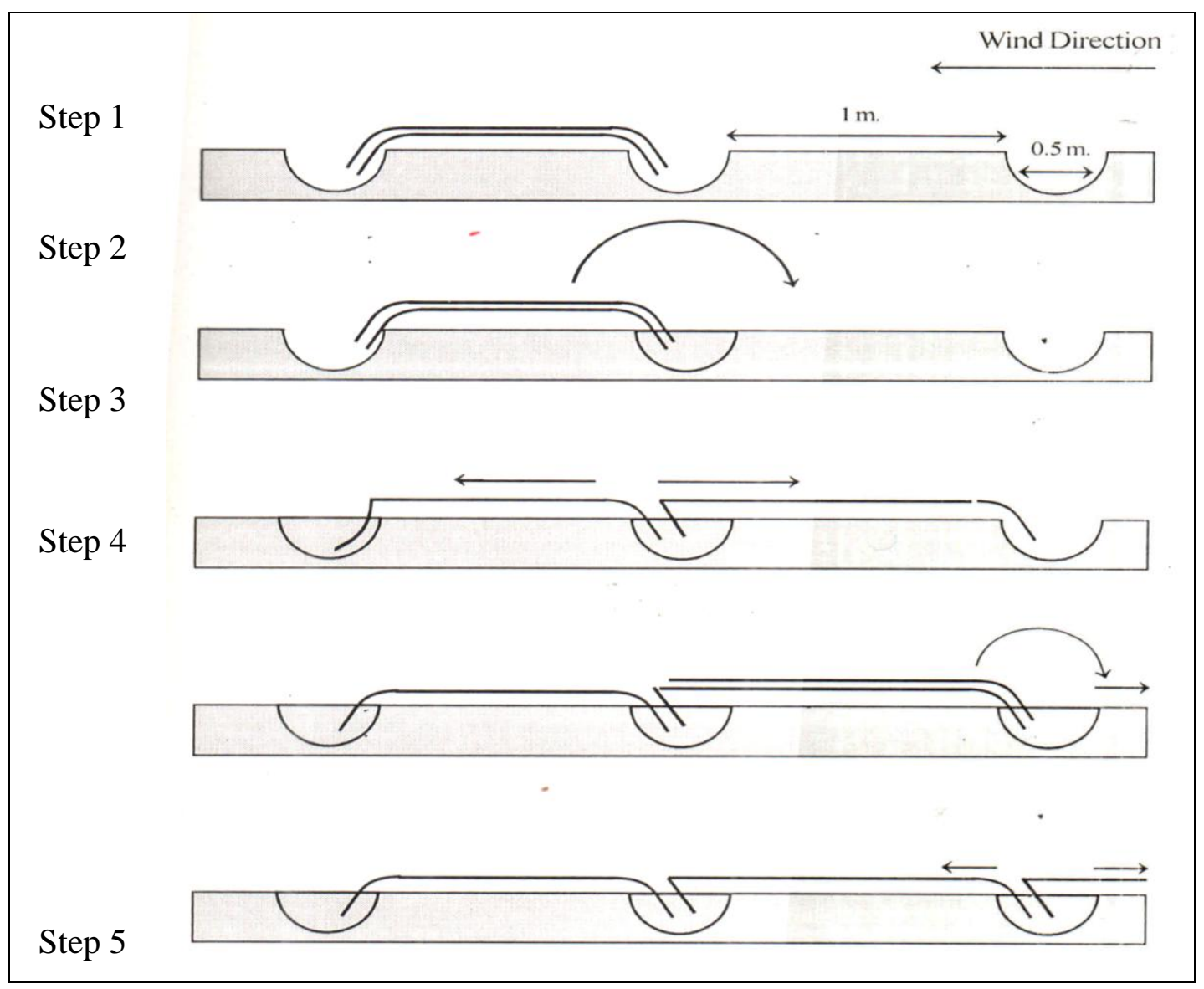


Fig.2a Changes in soil temperature during four weeks of solarization

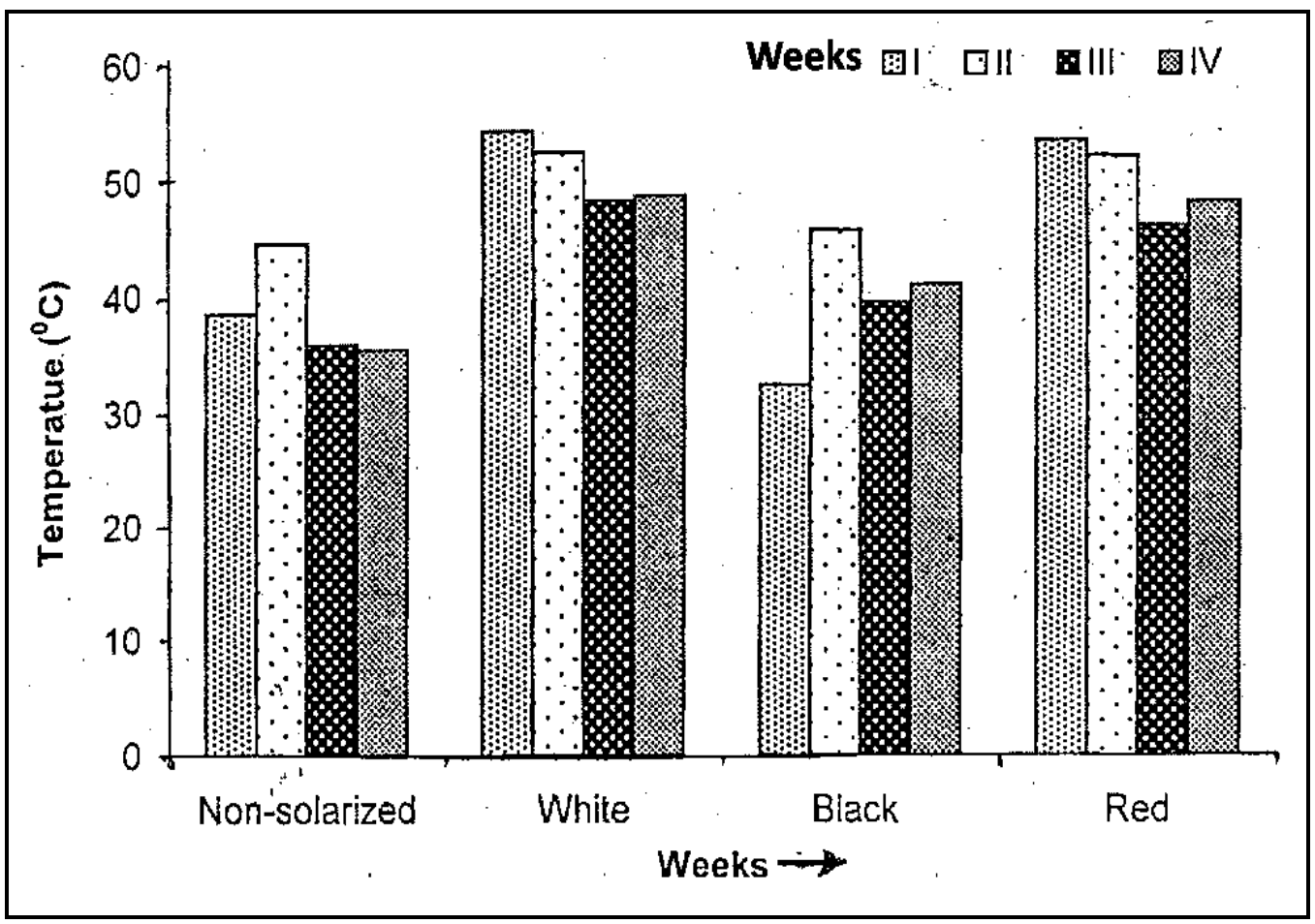

Fig.2b Effects polyethylene thickness on soil temperature

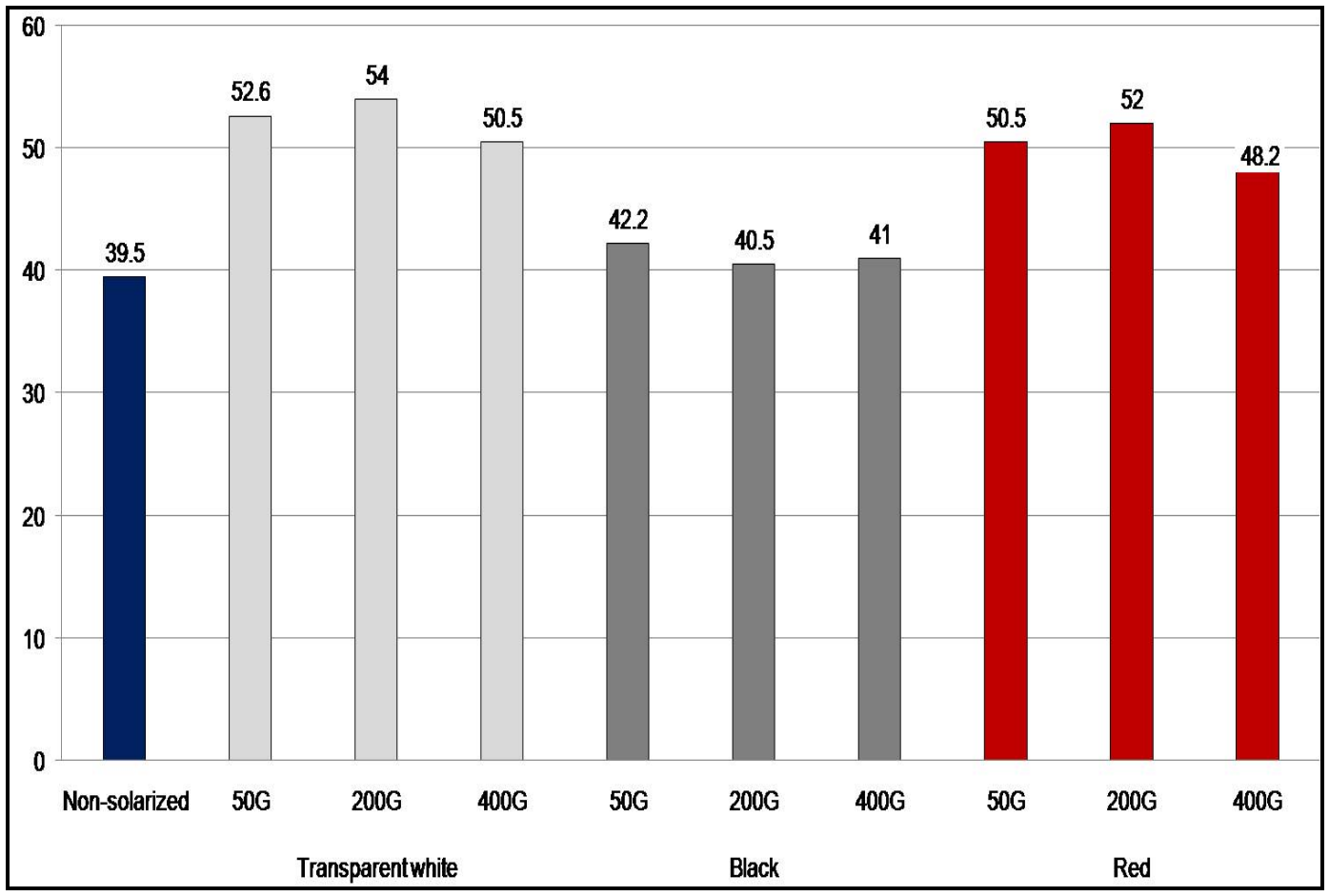


Fig.3 Solarization of nursery beds
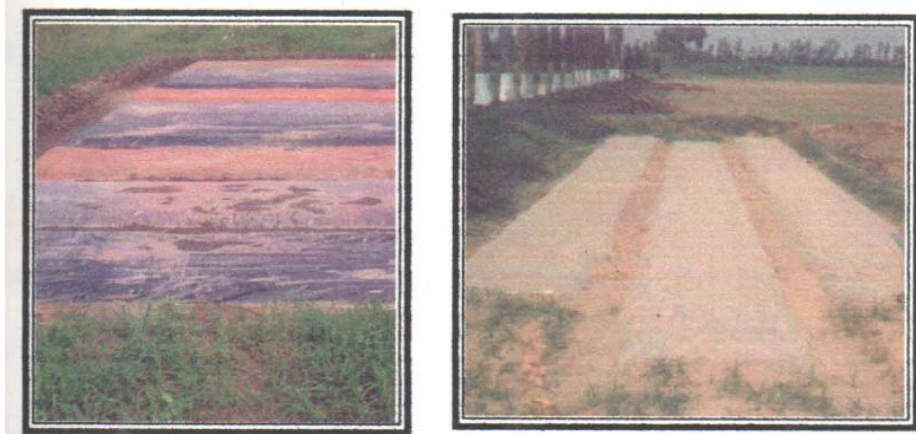

(a) Solarization of nursery beds

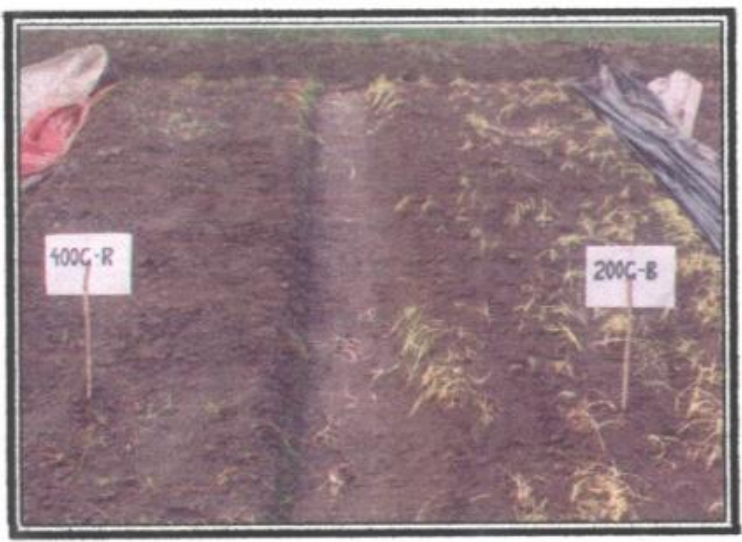

(c) Red polyethylene

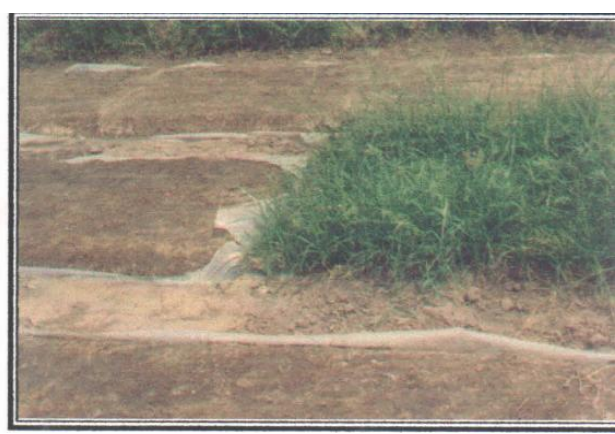

(b) White transparent polyethylene

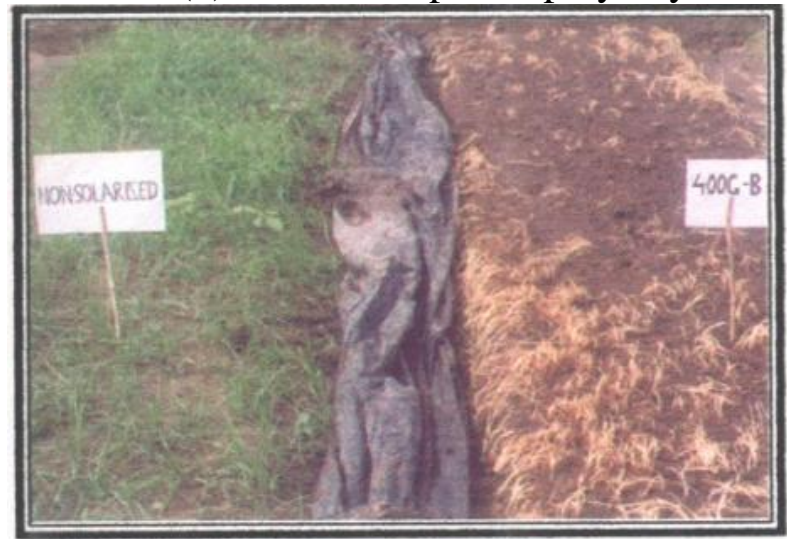

(d) Black polyethylene

Fig.4 Per cent increase in seedling emergence over control

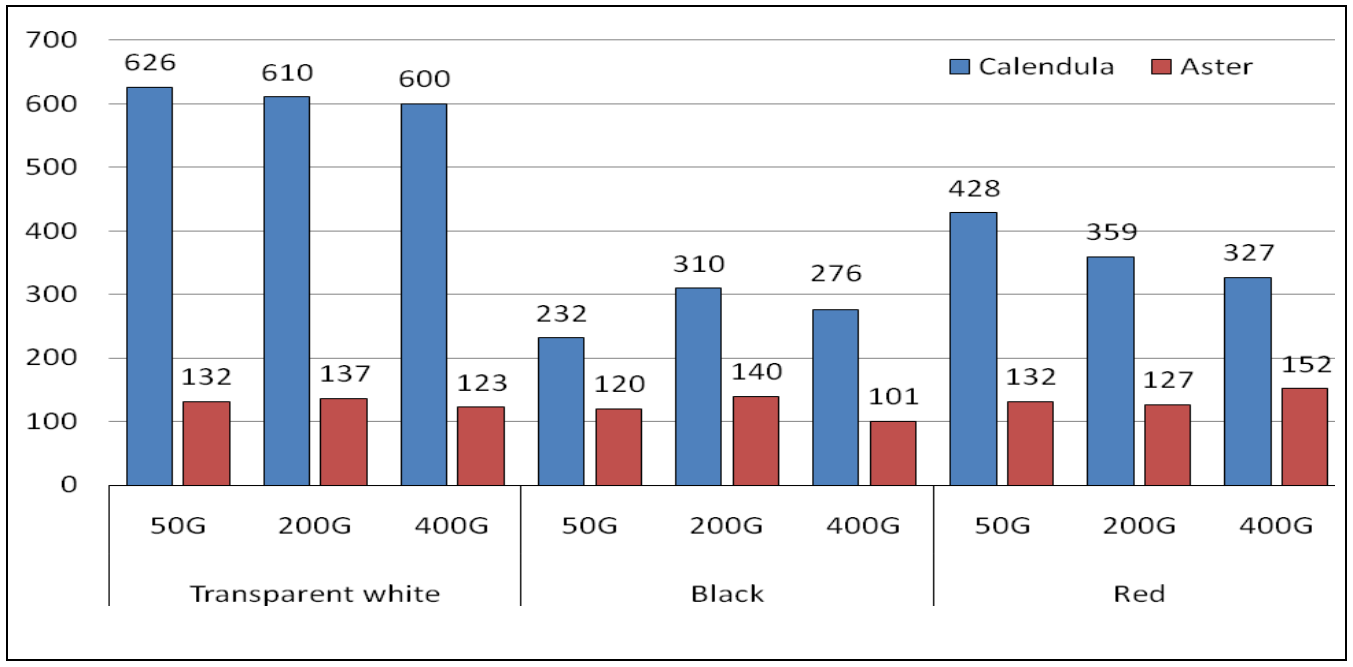

Nursery bed solarization also improved seedling fresh weight in both the nurseries. In case of calendula, maximum fresh shoot weight of seedlings $(5.3 \mathrm{~g})$ was recorded in plots solarized with 50 gauge white transparent PE sheet with Thiram seed treatment followed by $4.9 \mathrm{~g}$ with Vitavax seed treatment and $4.7 \mathrm{~g}$ with $T$. harzianum 
biopriming. The effect of seed priming with $T$. harzianum and $P$. fluorescens was significantly at par. Solarization with black and red PE sheet too significantly improved the fresh shoot weight for main plot factor, the thickness of the PE sheet as well as for the sub plot factor i. e. seed treatment /biopriming. The fresh shoot weight of seedlings improved to the tune of $3.45 \mathrm{~g}$ (biopriming with $P$. fluorescens) with 400G black PE sheet and $3.75 \mathrm{~g}$ (biopriming with $T$. harzianum) with 200G red PE sheet (Table 6).

In aster, it was recorded maximum $(14.8 \mathrm{~g})$ in case of plots solarized with 200 gauge white transparent PE sheet+ seed biopriming with $P$. fluorescens followed by solarization with WT $\mathrm{PE}+$ seed biopriming with $T$. harzianum as against $5.8 \mathrm{~g}$ in non solarized control plots. Although higher values of fresh shoot weight as compared to non solarized control were recorded in plots solarized with black and red PE sheet, the effect of solarization was statistically non-significant (Table 7). The improved seedling growth response may be attributed to increased concentration of soluble mineral nutrients generally reported in solarized soil $(11,19,33,34,35)$ prevalently due to the death and degradation/ decomposition of soil microbiota killed by the heat treatment. Integration of soil solarization with biofungicides has been reported to manage several soilborne pathogens $(7,9,31$, $38)$.

It is concluded in the present study, soil solarization with polyethylene sheet of different thickness and colour of the polyethylene film, showed significant reduction in incidence damping off and improvement in plant growth response of two ornamental crops; calendula and aster. Increased availability of plant nutrients is reported to contribute to marked increase in the growth, development, and yield of plants grown in solarized soil. Soil solarization is reported to increase soil electrical conductivity indicating higher availability of nutrients leading to relative increase in populations of rhizosphere competent bacteria, such as Bacillus spp. which contributed to the marked increase in the growth in solarized soil (34).

Soil solarization is an eco-friendly technique to manage soilborne pests, to maintain healthy crops and to preserve the environment through effective use of solar energy. Extensive research in past few decades has shown that the color and thickness of polyethylene sheet used for solarization may be taken into consideration to increase the efficiency of solarization and emphasis must be to adopt the technology as an integral component of crop production systems. In case of flowers where seed is a high value input, nursery disease management is of prime importance. In view of growing concerns towards conserving natural resources and residual toxicity of hazardous chemical pesticides, soil solarization proves to be an absolute technology in integration with seed bio-priming to combat soilborne plant pathogens in a sustainable manner with no harmful effects on soil and environment. Therefore, sustainable and eco-friendly technologies like soil solarization and seed biopriming must be given due weightage either alone or in integration, for nursery disease management in high value crops like ornamentals and vegetables

\section{Acknowledgement}

The financial assistance and necessary facilities provided by G.B. Pant University of Ag. \& Tech., Pantnagar, India, for conducting the study are duly acknowledged.

\section{References}

1. Agrios G. N. (2005). Plant Pathology. pp $410-427,5^{\text {th }}$ ed. Elsevier Academic Press.

2. Alkayssi A.W. and Alkaraghouli A.A. 1991. 
Influence of different colour plastic mulches used for soil solarization on the effectiveness of soil heating. 1st Int. Conf. on Soil Solarization 297-302.

3. Blok W.J., Lamers J.G., Termorshuizen A. and Bollen G.J. (2000). Control of soilborne plant pathogens by incorporating fresh organic amendments followed by tarping Phytopathology 90: 253-259.

4. Campiglia E., Temperini O., Mancinelli R. and Saccardo F. (2000). Effects of soil solarization on the weed control of vegetable crops and on the cauliflower and fennel production in the open field. Acta Hort. 533: 249-255.

5. Cascone G. and D'Emilio A. (2000). Effectiveness of greenhouse soil solarization with different plastic mulches in controlling corky root and knot-rot on tomato plants. Acta Hort. 532: 145 -150.

6. Chakrabarti B., Wontner-Smith T. and Bell, C. H. (1995). Reducing methyl bromide emissions from soil fumigation in greenhouses. pp 25-1 to 25-3. In: Annual International Research Conference on Methyl Bromide Alternatives and Emissions Reductions. Methyl Bromide Alternatives Outreach, Fresno, CA.

7. Chaube H.S. and Singh U.S. (1991). Plant Disease Management: Principle and Practices. C.R.C. Press F.L., U.S.A. 329 pp.

8. Chauhan Y.S., Nene Y.L., Johansen C., Haware M.P., Saxena N.P., Singh S., Sharma S.B., Sahrawat K.L., Burford J.R., Rupela O.P., Kumar J.V., Rao O.K. and Sithanantham S. (1988). Effect of soilsolarization on pigeonpea and chickpea. Research Bulletin II. ICRISAT Patancheru. $16 \mathrm{pp}$.

9. Chellemi D.O. (2006). Effect of urban plant debris and soil management practices on plant parasitic nematodes, Phytophthora blight and Pythium root rot of bell pepper. Crop Protection 25:1109-1116.

10. Chellemi D.O., Olson S.M., Mitchell D.J., Secker I. and McSorley R. (1997). Adaptation of soil solarization to the integrated management of soilborne pests of tomato under humid conditions. Phytopathology 87 (3): 250-258.

11. Chen Y., Katan J., Gamliel A., Aviad T. and
Schnitzer M. (2000). Involvement of soluble organic matter in increased plant growth in solarized soils. Biol. Fert. Soils 32, 28-34.

12. DeVay J.E. (1991). Use of soil solarization for control of fungal and bacterial plant pathogens including biocontrol. In: Proc. FAO Plant Prod. Prot. Paper 109: 79-93.

13. Elad Y., Katan J. and Chet I. (1980). Physical, biological and chemical control integrated for soil-borne disease in potatoes. Phytopathology 70: 418-422.

14. Freeman S. and Katan J. (1988). Weakening effect on propagules of Fusarium by sublethal heating. Phytopathology 78: 1656-1616.

15. Gamliel A. and Katan J. (2012). Soil Solarization: Theory and Practice

16. Gamliel, A. and Katan, J. (1992). Influence of seed and root exudates on fluorescent pseudomonads and fungi in solarized soil. Phytopathology 82: 320-327.

17. Gan J., Yates S.R., Wang D., and Ernst F.F. 1995. Reducing fumigant volatilization through optimized application and soil management. pp 26-1 to 26-2 In: Annual International Research Conference on Methyl Bromide Alternatives and Emissions Reductions: Methyl Bromide Alternatives Outreach, Fresno, CA.

18. Gasoni, L., Kahn N., Yossen V., Cozzi J., Kobayashi K., Babbit S., Barrera V. and Zumelzu G.(2008). Effect of soil solarization and biocontrol agents on plant stand and yield on table beet in Córdoba (Argentina). Crop Protection 27 (3-5): 337-342.

19. Katan J. (1987). Soil solarization. In: Innovative approaches to plant disease control. Chet I. (ed). John Wiley and Sons, New York.

20. Katan J. and DeVay J.E. 1991. Mechanism of pathogen control in solarized soils. Soil Solarization. pp 87-101. CRC Press, Boca Raton, FL.

21. Khulbe D., Chaube H.S. and Sharma J. (2001). Soil Solarization: An Eco-friendly approach to raise healthy seedlings of Horticultural Crops. In: Sinha A.; (ed.) Microbes and Plants. pp 158-187.Campus Books, New Delhi, India.

22. Lamichhane J.R., Durr C., Schwanck A.A., Robin M.H., Sarthou J.P., Cellier V., Messean A. and Aubertot, J.N. (2017). Integrated 
management of damping-off diseases: A review. Agron. Sustain. Dev. 37 (2), 25 p.

23. Lifshitz R., Tabachnik M., Katan J. and Chet I. (1983). The effect of sublethal heating on sclerotia of Sclerotium rolfsii. Can. J. Microbiol. 29: 1607-1610.

24. Mahrer Y. (1991). Physical principles of solar heating of soils by plastic mulching in the field and in glasshouses and simulation models. In: Katan J., DeVay J.E. (eds). Soil solarization. CRC Press, Boca Raton, Florida.

25. Menzies J.D. (1963). Survival of microbial plant pathogens in soil. Bot. Rev. 29:79-122.

26. Minuto A., Migheli Q., Garibaldi A. and Vanachter A. (1995). Integrated control of soilborne plant pathogens by solar heating and antagonistic microorganisms. Acta. Hort. 382: 138-143.

27. Minuto A., Spadaro D., Garibaldi A. and Gullino M.L. (2005). Control of soilborne pathogens of tomato using a commercial formulation of Streptomyces griseoviridis and solarization. Crop Protection 25 (5): 468-475.

28. Mishra D.S. (1997). Effect of soil solarization and its integration with fungicide and biocontrol agents on microbial population and seeding diseases of some vegetable crops. M. Sc. Thesis. G. B. Pant Univ. Ag. \&Tech., Pantnagar. 53.

29. Nair S.K., Peethambaran C.K., Geetha D., Nayar K. and Wilson K.I. (1990). Effect of soil solarization on nodulation, infection by mycorrhizal fungi and yield of cowpea. $P l$. Soil 125: 153-154.

30. Rao V.K. and Krishnappa K. (1995). Integrated management of Meloidogyne incognita, Fusarium oxysporum f.sp. cireri wilt disease complex in chickpea. Int. J. Pest Management 41: 234-237.

31. Rodrigo G., Smith A., Chaves B., Wyckhuys K., Forero C. and Jiménez J. (2009).
Combined efficacy assessment of soil solarization and bio-fungicides for management of Sclerotinia spp. in lettuce (Lactuca sativa L.) Agronomia Colbiana 27(2): 193-201.

32. Rosskopf E.N., Kokalis-Burelle N., Fennimore S.A. and Wilen C.A. (2015). Soil/Media disinfestation for management of florists' crops diseases. Handbook of florists' crops diseases, pp 1-33.

33. Sainamole K.P., Backiyarain S. and Rajkumar J. (2003). Effect of soil solarization on plant growth promotion. In: Reddy M.S., Anandaraj M., Sarma Y.R. and Kloepper J.W. (eds). Proceedings of 6th International PGPR Workshop, Indian Spices Society, Calicut, Kerala.

34. Stapleton J.J. and DeVay J.E. (1984) Thermal components of soil solarization as related to changes in soil and root microflora and increased plant growth response. Phytopathology 74: 255-259.

35. Stapleton J.J. and DeVay J.E. (1982). Effect of soil solarization on population of selected soilborne microorganisms and growth of deciduous fruit tree seedlings. Phytopathology 72: 323-326.

36. Stapleton J.J., Quick J., DeVay J.E. (1985) Soil solarization: effect on soil properties, fertilization, and plant growth. Soil Biol. Biochem. 17:369-373.

37. Stapleton J. J. (1997). Soil solarization an alternative soil disinfestation strategy comes of age. Sustainable Agriculture. 9: 7-9.

38. Stapleton J.J. and DeVay J.E. (1995). Soil solarization: A natural mechanism of integrated pest management. Pages 309-322. In: Innovative Approaches to Integrated Pest Management. Reuveni R. (ed). CRC Press, Boca Raton, Florida.

\section{How to cite this article:}

Deepa Khulbe. 2019. Integrating Soil Solarization and Seed Biopriming to Manage Seedling Damping-Off in Flower Nurseries. Int.J.Curr.Microbiol.App.Sci. 8(02): 1456-1469. doi: https://doi.org/10.20546/ijcmas.2019.802.169 